\title{
Simulando A Cadeia de Abastecimento de Alimentos Frescos: Os Efeitos da Variação da Temperatura $\mathrm{Na}$ Deterioração de Produtos Avícolas
}

\author{
Ana Paula Brizio (I), Bruna Andina Andrade (I), Carlos Prentice (I) \\ (I) FURG - Universidade Federal do Rio Grande (Av. Itália km 8 Bairro Carreiros )
}

\section{Resumo}

Carne de frango é um produto alimentar popular em todo o mundo. Muitos consumidores a preferem na forma "in natura" refrigerada, porém nestas condições a validade da carne é bastante pequena, não ultrapassando duas semanas. A sua deterioração está relacionada, sobretudo, a microorganismos advindos da contaminação industrial, e às condições favoráveis para o crescimento destes organismos, como abusos de temperatura durante o transporte e armazenamento. Assim, estudar o comportamento de deterioração química, física e microbiológica da carne de frango sob condições reais da cadeia de abastecimento é importante para conhecer o risco inerente à ingestão destes produtos. O objetivo deste trabalho foi investigar os efeitos da variação da temperatura na deterioração de produtos avícolas. Para isto, a vida-útil de cortes de frango refrigerados foi analisada em amostras submetidas a condições reais de transporte terrestre (acompanhamento da cadeia de distribuição) e, ao armazenamento sob simulação de diferentes temperaturas de estoque comercial e doméstico (padrão $3^{\circ} \mathrm{C}$; abuso 7 e $10^{\circ} \mathrm{C}$ ). Os resultados mostraram que para as rotas logísticas acompanhadas, apesar das oscilações de temperatura no interior do caminhão, a temperatura dos produtos manteve-se abaixo de $4^{\circ} \mathrm{C}$ durante todo o trajeto. Durante o armazenamento das amostras a 3, 7 e $10^{\circ} \mathrm{C}$ por doze dias, os resultados evidenciaram que um pequeno incremento na temperatura proporcionou mudanças na cinética de deterioração físico-química, assim como, uma acentuada aceleração do crescimento de micro-organismos deteriorantes e patogênicos, reduzindo

\footnotetext{
Referência:

Ana Paula Brizio, Bruna Andina Andrade, Carlos Prentice. Simulando A Cadeia de Abastecimento de Alimentos Frescos: Os Efeitos da Variação da Temperatura Na Deterioração de Produtos Avícolas. In: Anais do 12을 Congresso Latinoamericano de Microbiologia e Higiene de Alimentos - MICROAL 2014 [= Blucher Food Science Proceedings, num.1, vol.1]. São Paulo: Editora Blucher, 2014. DOI 10.5151/foodsci-microal-184
} 
rapidamente a validade dos produtos. Os cortes avícolas obtiveram uma vida-útil de dez dias em condições ideias de armazenamento $\left(3^{\circ} \mathrm{C}\right)$, enquanto as amostras estocadas a $7^{\circ} \mathrm{C}$ deveriam ser consumidas antes de completarem cinco dias de validade e aquelas mantidas a $10^{\circ} \mathrm{C}$ a partir do terceiro dia de armazenamento já representariam risco a saúde dos consumidos caso fossem consumidas. Com isso, estes resultados servem de suporte para o desenvolvimento de estratégias que visem o controle efetivo da temperatura durante a cadeia de abastecimento de produtos avícolas frescos, como medida para reduzir os índices de contaminação encontrados neste estudo.

Palavras-Chave: deterioração, produtos à base de frango, sanidade, controle de temperatura, cadeia de abastecimento

\section{Agência de Fomento:}

